\title{
195. Terminology in Bacteriology, with Special Reference to Cell Body, Macromolecular Layer in the Cell Wall and its Substructure
}

\author{
By Zensaku YoshiI \\ Department of Microbiology, Yamaguchi University School of Medicine, \\ Ube, Yamaguchi-ken, Japan 755 \\ (Comm. by Ren Kimura, M. J. A., Dec. 12, 1974)
}

Introduction. In 1953 the "macromolecular layer" (MML) was firstly demonstrated in the cell wall of Spirillum serpens by Houwink. ${ }^{1)}$ Since then, the existence of the MML has been recognized in the walls of various kinds of both Gram-positive and -negative bacteria by many workers, and the morphological properties of the MML, e.g. arrangement of the "unit structures" (US) in the MML, their shapes and sizes, and the subunit of the US have been described. Thus the anatomy of the wall was generally completed.2) On the other hand, the morphological characteristics of the virus particle were discussed by Lwoff and co-workers ${ }^{3}$ and the peculiar names such as virion, capsid and capsomer were also proposed by them for the virus particle and its substructures, respectively. Their considerations were proved to be true and their proposal was also accepted by the virologists after electron microscopy in the negative staining specimens initiated by Brenner and Horne. ${ }^{4)}$

Thus, the organization order of bacterial cells based upon the elementalism, especially the substructure system of the wall was recognized to be very similar to that of the capsid of virus particle.

Both systems are shown in parallel as follows:

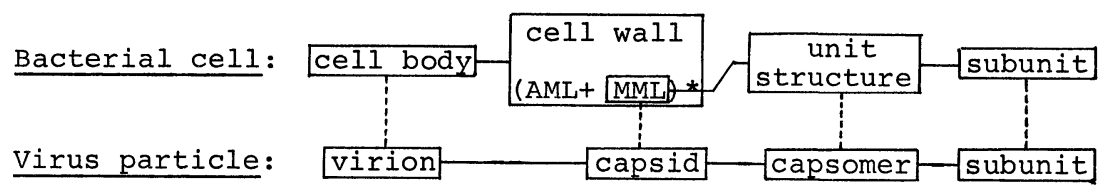

* $\mathrm{AML}=$ amorphous layer, $\mathrm{MML}=$ macromolecular layer

As above mentioned, the virus particle and its substructures were given their peculiar names, whereas the bacterial cell body and its substructures have not yet been named. Therefore, the naming of the latters was discussed in comparison with the former and their peculiar names were proposed in this paper. 
Organization of the bacterial cell, particularly of the sub-structures of the cell wall. It is considered that a bacterial cell body consists of some morphologically distinct structures, such as slime layer or capsule, cell wall, cytoplasmic membrane (CPM), cytoplasm and nucleus.

From the functional viewpoint, these structures are classified into two major groups. One is a group of an envelope or container and the other is a group of the contents which play the leading part of metabolism in the cell body.

The wall is thicker than the CPM and protects the contents as well as forming the shape of cell body with its higher degree of elasticity, ductility and rigidity. These properties of the wall were explained by the demonstration of the MML in the wall.7) The MML is relatively preservable than the "amorphous layer" (AML), so that the former was also regarded as the skeleton structure of the wall.7)

The MML is constructed from the unit structures sometimes called "unit granule",5) "unit particle",6) or "unit cylinder".7) The US varies in shape and size in the different bacteria. Four kinds of shapes, such as "spherical",8) "doughnut-shaped",9) "cylindrical" 7) and "cup-like",10) were reported. The distribution of their diametric sizes ranges from about 50 to $200 \AA$. The existence of the subunits was observed in the US.11),12)

The chemical composition of the subunits has not yet been clarified, however, they might be regarded as macromolecules because of their sizes.

The organization order of Bacillus aneurinolyticus is shown in Fig. 1 and of general bacteria is summarized in Fig. 2.

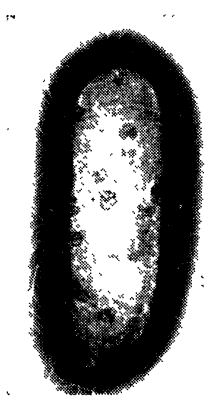

A whole cell body

(B. aneurinolyticus) $\underset{9,000 \times}{(\text { bacterion) }}$

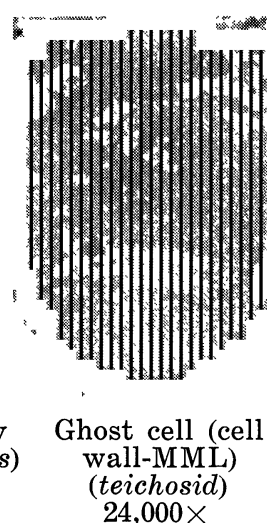

$24,000 \times$

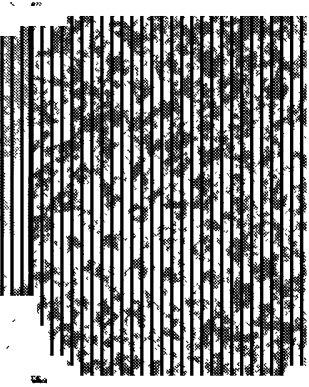

MML, showing unit structures (teichomers)

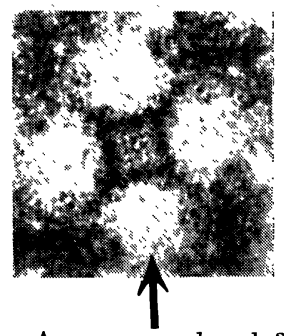

A macromolecule?

A teichomer, showing subunits by rotation method $3,000,000 \times$

Fig. 1. Electron micrographs of a Bacterial cell body and its substructures based upon the elementalism. 


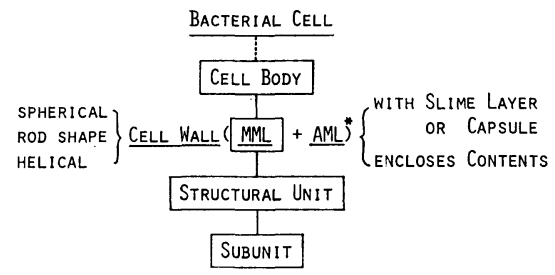

* MML = Macromolecular Layer, AML = AMorphous Layer

Fig. 2. Organization order in a bacterial cell based upon the elementalism.

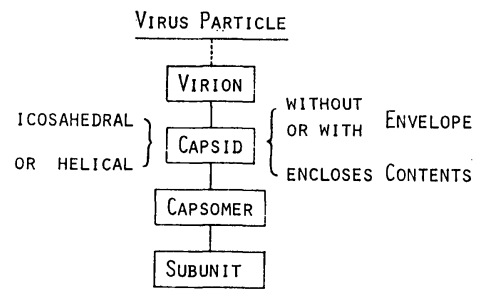

Fig. 3. Organization order in a virus particle based upon the elementalism.

Comparison of the organization between the virus particle and the bacterial cell. The facts above described remind us of the organization order and substructures of the virus particle. That is, the organization order in the bacterial cell is very similar to that in the virus particle as shown in Fig. 3.

The virion is an individual virus particle and is considered to be an infective unit. The capsid is the main body of a virion in which the genetic material is enclosed. Some of them are icosahedral and the others are helical; some of them possess the envelope and others lack it.

The capsomer is the US of the capsid. Subunit images of the capsomers in some viruses were obtained by the rotation method.13)

The organization orders of both the virus particle and the bacterial cell with special reference to the wall are summarized in Table I.

Table I. Comparison between viruses and bacteria* in their organization orders and names

\begin{tabular}{|c|c|c|c|c|}
\hline & \multicolumn{2}{|c|}{ Viruses } & \multicolumn{2}{|c|}{ Bacteria } \\
\hline & Common name & Peculiar name & Common name & $\underset{\text { name }^{* *}}{\text { Peculiar }}$ \\
\hline $\begin{array}{l}\text { Infective unit or } \\
\text { individual }\end{array}$ & Virus particle & virion & $\begin{array}{l}\text { Bacterial } \\
\text { Cell body }\end{array}$ & bacterion \\
\hline $\begin{array}{l}\text { Main structure, } \\
\text { enclosing } \\
\text { genome and } \\
\text { other contents }\end{array}$ & Box or shell & capsid & $\begin{array}{l}\text { Cell wall } \\
\text { (MML } \\
\text { + AML) }\end{array}$ & teichosid \\
\hline Structural unit & Part of box & $\begin{array}{l}\text { capsomer } \\
\text { (granular) } \\
\text { (cylindrical) }\end{array}$ & $\begin{array}{l}\text { Unit structure } \\
\text { (granular) } \\
\text { (cylindrical) }\end{array}$ & teichomer \\
\hline Subunit & \multicolumn{2}{|c|}{ Elements may be present } & \multicolumn{2}{|c|}{ Elements may be present } \\
\hline
\end{tabular}

* Cell wall which is a distinctly differentiated organelle of the bacterial cell is described in this table.

** This column shows the tentative names of bacterial substructures and they will be discussed in the following section. 
It is explained that there are many differences between the virus particle and the bacterial cell in their morphological characteristics, e.g. the former is smaller, simpler and more primitive than the latter.

However, similarities and common characters also can be recognized between them. Especially, both the capsid and the MML represent the peculiar shape of each microorganism with the common order of organization (substructure system) respectively, and possess a function as the container for genetic materials and others. As a remarkable difference, the former is smaller with fewer number of the US than the latter. Therefore, it is considered that they hold the same rank in the organization order of each individual with the differences on the scale of whole body and in number of the US. The capsomer and the US of the MML resemble each other in shape (granular or cylindrical) and in size (around $100 \AA$ ).

Naming of the bacterial cell and its substructures. Each substructure in the bacterial cell organization, such as the cell body, the MML in the wall, and the US of the MML, does not have its own peculiar name now as above mentioned. Therefore, their peculiar names may be proposed with the discussions of naming procedures after the examples in virus by Lwoff and co-workers. ${ }^{3)}$

1) The cell body. A bacterial cell body is similar to a virion (virus particle) in the organization order, so that the imitation of the naming procedure of virion is reasonable. The virion must be a compound of two words, virus and on. The word of on is Greek which means "being", and is sometimes used as a suffix for the calling of the elementary particles and quantam such as electron, proton and ion in physics. Lwoff and co-workers ${ }^{3)}$ might have thought of the original meaning and customary usage of $\mathrm{on}$. These discussions can be summarized as follows:

$$
\text { virus }+ \text { on }-\rightarrow \text { virion }
$$

Bacterial cell bodies are larger than virus particles in general, however, they are still smaller than $10 \mu$ and each of them can be regarded as a kind of particle. In fact, they are usually treated as particles in suspension for several counting methods of cell bodies, e.g. the turbidimetry-nephelometry ${ }^{14)}$ and coulter count method. ${ }^{15)}$ Moreover, there is no size limit regarding the usage of on. Therefore, the following procedure in the naming of bacterial cell body can be admitted.

$$
\text { bacterium }+ \text { on } \rightarrow \text { bacterion }
$$

2) The MML in the wall. The MML is regarded as a similar structure to the capsid because of its morphological and physiological properties as above mentioned, consequently this structure can be 
named in a way similar to that of the capsid. The capsid was induced

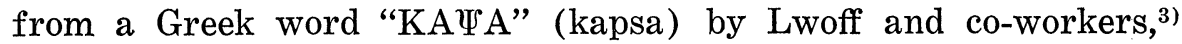
which means box or bag, and was regarded as a container of the genetic materials. They spelled capside in French and capsid in English. ${ }^{3)}$

The author would like to induce the peculiar name of the MML from a Greek word "TEIXO $\Sigma$ " (teikhos) which means the wall, because the MML is the main structure of the wall as above mentioned. Consequently, the naming procedure is reasonable as follows:

\begin{tabular}{ccc} 
Greek & Pronunciation & English style \\
\hline TEIXO $\Sigma$ & (teikhos) & teichosid
\end{tabular}

3) The unit structure of the $M M L$. The name of capsomer was introduced from a compound of two Greek words as shown in Table II. ${ }^{3)}$

Table II. Naming procedure of "capsomer" by Lwoff et al.3)

\begin{tabular}{|c|c|c|c|}
\hline & Origin & Spelling of & uliar name \\
\hline & Greek & French & English \\
\hline $\begin{array}{l}\text { Combination } \\
\text { Pronunciation } \\
\text { Meaning }\end{array}$ & $\begin{array}{l}K A \Psi A+M E P O \Sigma \\
\text { (kapsa) (meros) } \\
\text { Box or bag Part }\end{array}$ & $\begin{array}{l}\text { capsomeres } \\
\text { kapsomər } \\
\text { (Part of box) }\end{array}$ & $\begin{array}{c}\text { capsomer } \\
\text { kæpsomə } \\
\text { (Part of box) }\end{array}$ \\
\hline
\end{tabular}

Accordingly, the name of teichomer can be given to the US of the MML in the sense of "part of teichosid" after the naming of capsomer, because the US is a constituent of the MML. The naming procedure of the teichomer is shown in Table III.

Table III. Naming procedure of "teichomer" by Yoshii (1974)

\begin{tabular}{|c|c|c|c|}
\hline & \multirow{2}{*}{$\begin{array}{l}\text { Origin } \\
\text { Greek }\end{array}$} & \multicolumn{2}{|c|}{ Spelling of peculiar name } \\
\hline & & French style & English \\
\hline $\begin{array}{l}\text { Combination } \\
\text { Pronunciation } \\
\text { Meaning }\end{array}$ & \begin{tabular}{|cc}
$T E I X O \Sigma+M E P O \Sigma$ \\
(teikhos) & (meros) \\
Wall & Part
\end{tabular} & $\begin{array}{c}\text { téichomeres } \\
\text { teifomər } \\
\text { (Part of wall) }\end{array}$ & $\begin{array}{c}\text { teichomer } \\
\text { teikhomə } \\
\text { (Part of wall) }\end{array}$ \\
\hline
\end{tabular}

Conclusion. Because of similarities and common characteristics in the organization between the bacterial cell body and the virus particle (virion), the macromolecular layer (MML) in the cell wall and the capsid, and the unit structure (US) of the MML and the capsomer, the peculiar names were given to the cell body, the MML in the wall, and the US of the MML after the naming procedures of virion, capsid and capsomer. 
Those peculiar names are "bacterion" (cell body), "teichosid" (MML in the wall), and "teichomer" (US of the MML), respectively. Acknowledgement. The author wishes to offer his thanks to Dr. Ren Kimura, Member of Japan Academy and Professor Emeritus of Kyoto University, for his constant encouragement.

\section{References}

1) Houwink, A. L.: Biochim. Biophys. Acta., 10, 360 (1953).

2) Glauert, A. M., and M. J. Thornley: Ann. Rev. Microb., 23, 159 (1969).

3) Lwoff, A., et al.: Ann. inst. Pasteur, 97, 281 (1959).

4) Brenner, S., and R. W. Horne: Biochim. Biophys. Acta, 34, 103 (1959).

5) Yoshii, Z., et al.: J. Electron Microscopy, 17, 67 (1968).

6) Yoshii, Z.: Proc. Japan Acad., 49, 633 (1973).

7) —-: Zbl. f. Bakt. Hygiene (in press).

8) Labow, L. W., and V. M. Moseley: Biochim. Biophys. Acta, 15, 325 (1951).

9) Matsumoto, A., and G. P. Manire: J. Bacteriol., 104, 1332 (1970).

10) Remsen, C. C., et al.: J. Bacteriol., 103, 255 (1970).

11) Murray, R. G. E.: Canad. J. Microbiol., 9, 381 (1963).

12) Yoshii, Z.: Japanese J. Bacteriol., 29, 141 (1974).

13) Markham, R., et al.: Virology, 20, 88 (1963).

14) Mallete, M. F.: Methods in Microbiology (edited by J. R. Norris and D. W. Ribbons). Academic Press (London and N. Y.), I, 521 (1963).

- 15) Kubitschek, H. E.: Methods in microbiology (edited by J. R. Norris and D. W. Ribbons). Academic Press (London and N. Y.), I, 593 (1969). 